\title{
Spotkajmy się - wszyscy jesteśmy teoretykami!
}

\section{Let's Get Together - We Are All Theorists!}

\begin{abstract}
Theoretical approach to politics is the domain of emotional disputes, antinomies connected with the interpretation of the phenomenon of science, or the reason for insoluble controversies, concerning the foundations of recognized worldviews. Both social sciences and humanities participate in this discussion, in their own specific way; political science and the theories developed within this domain can be positioned between them. This discussion, however, bears no signs of a matter of fact debate, it is conducted in breach of the principles of scientific rationality. Many a time it has a confessional character: the arguing parties, instead of presenting their own positions in a discursive way, and quoting appropriate arguments, often resort to presenting their own "confession of faith" and use it as a starting point to denigrate the opponent. It is the author's opinion that social theory and the theories of politics investigated within its frame would help to find and understand the origins of opposing worldviews.
\end{abstract}

Keywords: social sciences, social theory, theory of politics, theorizing, the phenomenon of science

To, jak się rozumie teorię polityki i jakie funkcje przypisuje się temu „produktowi”, wiąże się ściśle ze „stylem”, w jakim uprawiana jest politologia, a więc pośrednio zależy od tego, jak się pojmuje fenomen nauki i co za tym idzie - „naukowość" politologii. W konsekwencji status (ocena) teorii politologicznych jest związany z kondycją politologii jako dyscypliny naukowej, to zaś, jak się widzi i ocenia wartość poznawczą „teorii”, staje się funkcją rozumienia „nauki”. Nauka to nie tylko kolekcja faktów i „skrzynek z narzędziami” do ich ustalania, ale także refleksja metanaukowa, czyli ciągła potrzeba testowania naszych roszczeń do wiedzy, nieustanny namysł nad statusem oraz tymczasowym charakterem twierdzeń naukowych.

Rozważanie tych splątanych, a zarazem jakże fascynujących kwestii stanowi oś niekończących się dyskusji prowadzonych z różnym nasileniem i towarzyszących naukom społecznym od chwili ich instytucjonalizacji; tym bardziej zagma- 
twanych, że fenomenowi nauki i jej szczególnemu wytworowi - teorii - z perspektywy historycznej, kulturowej i epistemologicznej poświęca się w społecznej świadomości zdumiewająco mało refleksyjnej uwagi ${ }^{1}$.

Można ten stan rzeczy uznać za osobliwy w sytuacji, gdy obecność nauki i technologii w naszym życiu jest wszechobecna i natarczywa. Jednakże, albo uznaje się ją bezrefleksyjnie za codzienną oczywistość, albo reaguje nań z niejasnym poczuciem nieodwracalnego, technologicznego zagrożenia. Tym bardziej elementarna wiedza o nauce - jak jest wytwarzana, do czego służy i jak działa, o jej metodzie, strukturze, ambicjach, możliwościach i ograniczeniach, o jej gorzkich i kłopotliwych owocach - wydaje się czymś nieodzownym dla współczesnego, wykształconego człowieka. Ponieważ to właśnie nauka, jak żadne inne przedsięwzięcie nowożytności, dzięki swej własnej dynamice poznawczej, ukształtowała i nadal kształtuje stosunki społeczne. - Czym jest społeczeństwo, a pośrednio też i polityka, to dziś określa nauka.

Wraz z lawinowymi przewrotami naukowymi i ich technicznymi realizacjami w perspektywie nieustającego postępu pojawiła się pogłębiona i krytyczna metarefleksja nad nauką, cechująca się dystansem wobec przedmiotu badania oraz powiązana $\mathrm{z}$ dualistycznym charakterem samej nauki i jej teoriami, ukrytym pod nazwą „dwóch kultur” według C.P. Snowa (1993). Oto nauka obejrzana „od wewnątrz”, w perspektywie antropologicznej i historycznej, została ujawniona jako zjawisko kulturowe, przygodne, kontyngentne i wkroczyła do krytyczno-hermeneutycznych nauk społecznych i nauk o kulturze. Taki jej ogląd sprawił, że stała się podejrzana dla przyrodoznawców i nauk społecznych uprawianych w stylu science. Jednakże rozwinięcie refleksji o nauce usytuowanej „na zewnątrz", w zewnętrznej, przedmiotowej domenie, wymagającej podejścia analityczno-empirycznego i fachowej kompetencji badacza mającego odpowiednie wykształcenie uczyniło ją czarną magią dla kulturoznawców i humanistów.

Zmiany zachodzące $\mathrm{w}$ postrzeganiu i rozumieniu nauki odnotowywane w badaniach umiejscowionych w perspektywie diachronicznej i antropologicznej zmieniają pytanie o to, jak wytwarzana jest wiedza naukowa dotycząca danego przedmiotu badania, na pytanie, jaką rolę odgrywa jego „plastyczność” ujawniająca się w kulturowych, społecznych i instrumentalnych (metodologicznych) kontekstach o zróżnicowanych zawartościach. Rozważanie tych kwestii unaocznia znaczenie, jakie dla pozyskiwania wiedzy naukowej mają warunki formowania i osadzania w systemie metodologicznym danego przedmiotu badania;

Mimo że pisałam ten artykuł jako odrębną pracę, w wielu jej miejscach wykorzystane zostały pomysły, zdania i akapity pochodzące z wcześniejszych moich publikacji. Przy okazji dziękuję moim Kolegom studiującym z pasją podobne zagadnienia, którzy dzielili się ze mną swoją wiedzą i wzbogacili moje myślenie. 
pozwala dostrzec odwrót od „rzeczy” ku „konfiguracjom”, a także rozdźwięk między „reprezentacjami”, odwołującymi się do eksperymentu, obserwacji i pomiaru, a „prezentacjami” - opisywanymi w monografiach nauk humanistyczno-hermeneutycznych i literaturze popularno-naukowej (Rheinberger, 2015, s. 300-302).

W obrębie współczesnej pluralistycznej politologii koegzystują i ścierają się najrozmaitsze orientacje teoretyczne, posługujące się niekiedy zasadniczo odmiennymi kryteriami naukowości. Oprócz teorii uznanych już i w miarę powszechnie obecnych w standardowych podręcznikach do politologii pojawiają się coraz to nowe ich wersje odwołujące się do nurtu krytycznych i postmodernistycznych nauk społecznych, którym znacznie trudniej zachować jasność myśli i dojść do porozumienia i w których interpretacja wyników jest najmniej pewna.

Wydaje się, że można ograniczyć to zamieszanie, poprzestając na wskazaniu jedynie dwóch głównych nurtów kształtujących tradycje naukowych badań teoretycznych, związanych z namysłem nad tym, co polityczne. Teorię można uprawiać, odwołując się do wyobraźni i z pozycji aprioryzmu, i ze stanowiska aposterioryzmu - czyli działalności i wiedzy związanej z bazą empiryczną; obie tradycje mają swój wymiar czasowy, kontekst kulturowy, są wewnętrznie zróżnicowane, trudne do uporządkowania i równie ważne dla refleksji nad społeczno-politycznym wymiarem ludzkiej egzystencji. To dzięki nim, napięciu, jakie wytwarzają, istotne aspekty ludzkiego życia, takie jak moralność i racjonalność, mogą być zrozumiane w kontekście światopoglądu zainspirowanego przez naukę.

Pierwsza z nich ma historię najdłuższą, związana jest $\mathrm{z}$ refleksją filozoficzną, aksjologicznie zaangażowaną, poddającą analizie zbiory problemów nietracących przez wieki na atrakcyjności i zajmującą się głównie wyjaśnianiem natury dobrego życia oraz wytyczaniem granic wolności i sprawiedliwego społeczeństwa; jej fundament stanowi aspiracja zasadzająca się na obiektywistycznych koncepcjach sprawiedliwości i „ludzkiego dobrobytu”. Etyczny i normatywny charakter tej tradycji ujawnia się w hipotezach lub innego rodzaju stwierdzeniach orzekających o tym, co jest właściwe, a co niewłaściwe, pożądane albo niepożądane, słuszne lub niesłuszne w społeczeństwie.

$\mathrm{Z}$ jednej strony mieszczą się $\mathrm{w}$ tym podejściu rozważania tak ważnych zagadnień politycznych, jak natura sprawiedliwości, istota i cel władzy, normatywny charakter porządku społecznego czy też spekulacje na temat wolności, z drugiej zaś wiedza o instytucjach politycznych zdolnych do zapewnienia tych dóbr. W tym filozoficznym kontekście teorie polityki wiążą się $\mathrm{z}$ analitycznym badaniem podstawowych dla myśli politycznej idei i doktryn - od Platona i Arystotelesa do Karola Marksa, Michela Foucaulta, Johna Rawlsa, Roberta Nozicka czy Jacques’a Derridy - i tradycyjnie przybierają formę historii myśli politycznej; 
układają się w opowieść o dziejach czynników ideacyjnych motywujących politykę i zachowania polityczne w danym miejscu i czasie (Skinner, 1990).

Badając cele władzy, środki działania politycznego, filozoficzne teorie polityki stawiają pytania o charakterze etycznym i normatywnym, a przy okazji krytycznie analizują wkład, jaki znaczący myśliciele - od starożytności po współczesność - wnieśli w nasze rozumienie tych problemów oraz objaśniają i doprecyzowują pojęcia stosowane w debatach politycznych.

Pojawienie się nauk społecznych na przełomie XIX i XX wieku staje się inspiracją dla tworzenia drugiej - równie ważnej - tradycji badań teoretycznych związanych z namysłem nad polityką. Początkowo daje się obserwować spadek popularności filozoficznej teorii polityki, a nawet ogłoszenie śmierci filozofii politycznej i zakończenia wieku ideologii (Laslett, 1956; Bell, 1960); tak jakby okres dwóch tysięcy lat uprawiania filozofii inspirowanej zjawiskami świata społecznego dobiegł nagle końca. Do głosu dochodzą przedstawiciele nauk społecznych związani z podejściem behawioralnym, domagający się nadania wymiaru naukowego zagadnieniom odnoszącym się do rzeczywistości społecznej i opowiadający się za zaniechaniem badań wielkich systemów filozoficznych przeszłości, z ich budzącą wątpliwości mieszaniną elementów opisowych i krytycznych, po to, aby zająć się prawdziwie naukową próbą konstruowania czegoś, co zwykło się nazywać „teoriami empirycznymi” zachowań społeczno-politycznych. Podkreślano, zajmując pozycję aposterioryzmu, że w centrum analizy społecznej i politycznej należy umieścić dające się obserwować zachowania, a wszelkie ich wyjaśnienia powinny się poddawać weryfikacji empirycznej.

Oprócz spychanej na dalszy plan, filozoficznej, normatywnej teorii polityki zaczęła się kształtować odmienna, wąsko rozumiana, empiryczna jej wersja; wolna od ocen, pozbawiona ambicji normatywnych, wyraźnie zależna od wyobrażeń na temat tego, czym jest nauka i co powinno odróżniać naukową wiedzę o polityce od wszelkich innych jej form. Upowszechnia się przekonanie, że propozycje, których się nie da zweryfikować w sposób empiryczny, są po prostu bez znaczenia. Teoria polityki przestaje być terenem filozoficznych oraz historycznych rozważań inspirowanych namysłem, jak należy organizować porządek społeczny i dobre państwo, a staje się produktem politologicznych badań naukowych, które mają obowiązek bycia empirycznymi, a zarazem teoretycznymi - przy czym termin „teoria naukowa” zaczyna być inaczej definiowany (Krauz-Mozer, 1992).

Początkowo niektórzy metodolodzy i przedstawiciele pewnych kierunków filozofii nauki zbliżonych do pozytywizmu postulowali restryktywny model teorii naukowej, nakładając nań wiele warunków formalnych, trudnych bądź niemożliwych do spełnienia, zwłaszcza w naukach społecznych. Za model doskonały uznano teorię aksjomatyczną, uporządkowaną w system dedukcyjny, w którym 
między twierdzeniami zachodzi stosunek wynikania logicznego, co umożliwia wyjaśnianie jednych twierdzeń przez inne czy też dedukowanie nowych praw ze zbioru już wcześniej przyjętych aksjomatów. Prestiż analizy dedukcyjnej i metody matematyczno-empirycznej sprzyjał akceptacji przekonania, że podstawą wyjaśniania, także dla zjawisk społeczno-politycznych, są istniejące między nimi zależności przyczynowo-skutkowe. Taki pogląd wymagał przyjęcia założenia, według którego ludzkie działania można traktować i tłumaczyć w tych samych kategoriach, w jakich wyjaśnia się zjawiska naturalne.

Jednakże ów kanoniczny ideał, zwłaszcza w naukach społecznych, stał się „nieurzeczywistnionym projektem”; w jego miejsce przyjęło się w tych dyscyplinach uznawać za teorię zestaw założeń, definicji i wzajemnie ze sobą powiązanych i uporządkowanych rzeczowo, abstrakcyjnych twierdzeń, które umożliwiają usystematyzowanie wiedzy o życiu społeczno-politycznym, jego wyjaśnienie i przepowiedzenie przyszłości, a także wysunięcie nowych hipotez badawczych (Faia, 1986). Taka „rozluźniona” definicja ma swoje zalety, pasuje do wielu systemów myślowych, którym brakuje formalnych elementów, a mimo to mogą być przez badaczy uważane za teorie naukowe.

Teorię postrzega się nadal jako konieczne narzędzie badawcze, ponieważ ułatwia uporządkowanie - jeżeli nie logiczne, to przynajmniej rzeczowe i umożliwia klasyfikację wiedzy obserwacyjnej, ujawnia relacje między zjawiskami pozornie odległymi, skłania do zbierania nowych danych, które bez teorii nie byłyby dostrzeżone, wskazując tym samym nowe kierunki badań. Politolodzy, dzięki względnie zdefiniowanemu językowi i rozumowaniu teoretycznemu, uwolnili się od myślenia uwikłanego w potoczne oczywistości, spekulatywne koncepcje i domysły rodem $\mathrm{z}$ „Archiwum X”. Analiza politologiczna, wsparta na fundamencie wiedzy teoretycznej i empirycznej zarazem, łatwiej pokonywała fasadowe pozory, podważała propagandowe hasła i zdroworozsądkowe opinie, odsłaniała ukryte mechanizmy życia politycznego. Ostatecznie teorie empiryczne stały się uznanym i koniecznym narzędziem poznania i wyjaśniania rzeczywistości społeczno-politycznej.

We współczesnej politologii zainteresowanie refleksją teoretyczną ujawnia się w trwających nadal - i przebiegających z różnym natężeniem - debatach akademickich, w których empiryczna "teoria polityki” stanowi hasło wywoławcze do dyskusji nad różnymi formami przedstawiania i wyjaśniania świata, dla których podstawy pośrednio empirycznej dostarcza obserwowanie form relacji zachodzących między zjawiskami poddającymi się obserwacji. Siłą empirycznej politologii jest to, że w metodzie, jaką się posługuje w badaniach, elementy teoretyczne łączą się z danymi doświadczalnymi. Szczegółowa analiza tej relacji unaoczniła wysoce problematyczną naturę ustalanych faktów; utracono wiarę w możliwość dotarcia do „nagich faktów” i pojawiło się ostrzeżenie przed ogra- 
niczonym i zawodnym doświadczeniem zmysłowym, które nietestowane może wspierać postawę „naiwnego realizmu”. Jednakże, w szerszym kontekście, określenie „empiryczne” nadal odnosi się do wykorzystywania danych, zebranych dzięki pośrednim i bezpośrednim obserwacjom, jako głównego sposobu uzyskiwania wiedzy o świecie.

Owo przenikanie się teorii i doświadczenia zmysłowego uznane zostało za cechę ludzkiego poznania w ogóle; $w$ tej perspektywie doświadczenie nie jest tylko bierną rejestracją bodźców, lecz czymś nierozerwalnie związanym z myśleniem teoretycznym (Heller, 2016, s. 109). Metodologiczny rdzeń współczesnej nauki można odnaleźć w utrzymującej się interakcji między podejściem empirycznym a racjonalnym - właśnie z niej czerpie ona swoją siłę. Wszakże wzajemna zależność między czynnikami empirycznymi i racjonalnymi oraz czynnikiem ludzkim, który stanowi część tej mikstury, nie jest łatwą sprawą.

W konsekwencji konstruowanie w politologii teorii empirycznej jawi się jako problem, coraz to bardziej zagmatwany i generujący wiele zróżnicowanych, oddzielnych stanowisk, w miarę jak polaryzują się nasze poglądy dotyczące tego, na czym ma polegać „,naukowość” dyscyplin badających świat zjawisk społeczno-politycznych (della Porta, Keating, 2008).

Jest to konstatacja tym bardziej niepokojąca, że szybko zmieniająca się rzeczywistość społeczno-polityczna ujawnia zaskakująco nowe problemy i napięcia. Dostępne człowiekowi technologie, zwłaszcza informacyjne i komunikacyjne, mają wpływ na kształt życia społeczno-politycznego; stwarzają nowe środowisko, w którym pojawiają się nowe formy interakcji, mechanizmy socjalizacji, typy ról społecznych, zasady funkcjonowania wspólnot i życia publicznego; wywołują przemiany kształtu pracy ludzkiej i całego globalnego systemu politycznego, gospodarczego i kulturowego. Świat społeczny postrzegany jest jako nieuporządkowany, niestabilny, pełen napięć i ryzyka, nie ma w nim trwałych struktur, praw i wartości - jest światem w procesie transformacji. Badania teoretyczne nie nadążają za narastającym tempem zmian! Teorie polityki zaczynają być postrzegane jako stały, nigdy niekończący się proces teoretyzowania (Alexander, 1982), a nie rezultat w skończonej zamkniętej postaci. Twierdzi się również, iż w tym odmiennym, ponowoczesnym świecie polityka zmieniła się do tego stopnia, że trzeba o niej myśleć inaczej. Najlepiej stosować wyjaśnienia bardziej zawężone, peryferyjne i zrezygnować $\mathrm{z}$ uniwersalnych i całościowych ambicji bądź nawet poniechać jakichkolwiek wyjaśnień i odrzucić tendencję do rozgraniczania poszczególnych dyscyplin.

Ponownie daje o sobie znać pilna potrzeba namysłu filozoficznego nad polityką; zwłaszcza w odniesieniu do takich kwestii, jak sprawiedliwość, wojny, społeczne przyczyny głodu, odpowiedzialność człowieka za świat przyrody, prawa zwierząt, ograniczona odpowiedzialność polityków czy prawa nienarodzonych. 
Empiryczne teorie polityki są $\mathrm{w}$ zasadzie bezradne wobec szczególnego charakteru współczesnej „polityczności”, a w konsekwencji tradycyjnie ukierunkowana problematyka politologiczna wymaga przeglądu i „świeżej” refleksji; jej rozważenie zmusza do etycznego namysłu i podjęcia próby wyznaczenia określonych celów dla podejmowanych działań politycznych, które przecież nie mogą być tylko „ślepymi” eksperymentami badawczymi (Sartori, 1994, s. 31-34). Dzięki temu filozoficzne teorie polityki odzyskują swoją dawną pozycję w systemach wiedzy politologicznej, a wśród badaczy upowszechnia się przekonanie, że aprioryczne idee są konieczne i stanowią instrumentalny konstrukt, wspomagający podmioty w osiąganiu ich celów (Goldstein, Keohane, 1993).

Dzisiejsza politologia jest wyraźnie dziedziną wieloparadygmatyczną i jednocześnie pluralistyczną, „rozmytą”, pozbawioną jasnych granic; te okoliczności przekładają się w widoczny sposób na myślenie teoretyczne, organizujące wysiłki badawcze podejmowane w tej dyscyplinie. Obecne w politologii koncepcje teoretyczne są bardzo zróżnicowane, podstawowe tradycje badań teoretycznych przemieszane; rozbieżności między nimi ujawnia analiza porównawcza elementów składowych struktury teorii. Mogą to być różnice tak fundamentalne i zasadnicze, że teorie stają się wzajem siebie niewspółmierne, mimo że dotyczą zbioru tego samego rodzaju danych - zjawisk społeczno-politycznych, tych już zaistniałych, poddających się obserwacji i tych dopiero pomyślanych i projektowanych.

Głębszy wgląd w to zamieszanie i szansę na odnalezienie się w nim stwarza "teoria społeczna”; zazwyczaj termin ten jest rozumiany jako względnie systematyczna, abstrakcyjna i ogólna refleksja nad działaniem świata społecznego; obejmuje rozmaite aspekty rzeczywistości społecznej, w różnych okresach i w różnych społeczeństwach (Baert, Carreira da Silva, 2013). Można ją postrzegać jako przegląd wszystkich tematów podejmowanych w naukach społeczno-historycznych; zarówno w empirycznych badaniach struktur i instytucji, jak i w analizowaniu debat na tematy społeczne, odkrywaniu znaczeń społecznych symboli, obrządków i mitów (Seidman, 2006, s. 44-55; Elliott, 2011; Szacki, 2002). Teoria społeczna próbuje je zrozumieć, zinterpretować i wyjaśniać, ale wskutek swej wewnętrznej różnorodności i złożoności wywołuje wiele sporów między paradygmatami funkcjonującymi w naukach społecznych. Niemniej jednak inspiruje, wymusza myślenie, jest czymś w rodzaju „trzeciego świata” Karla Poppera dla nauk społecznych i politycznych (Popper, 1992).

Można by nawet odnieść wrażenie, że podtrzymywanie tego napięcia stanowi swoistą osobliwość teorii społecznej; jego źródłem są idee filozoficzne mające fundamentalne znaczenie dla nauk społecznych. Przestrzeń, w której się pojawiają - wypełniona „pytaniami ostatecznymi”, odnoszącymi się np. do problematyki nieprzekraczalnych podstaw racjonalności czy zagadnień sensu i war- 
tości - jest zamknięta dla metod empirycznych. Owe idee, by dojrzeć, potrzebują odpowiedniej gleby. Dla nauki glebą taką jest dyskusja - spotkanie tych, którzy bezustannie mają wątpliwości i niezniechęceni poszukują dalej.

Jednakże prymarny charakter tych idei sprawia, że praca nad teorią społeczną nigdy nie jest skończona; tak jak nie kończą się polemiki i poszukiwania nowych rozwiązań dla starych problemów wynikających z fundamentalnego dla ludzkiego gatunku uwikłania w sieć relacji z innymi ludźmi - o odmiennych stanach mentalnych, różnie uporządkowanych wartościach i inaczej zdefiniowanych interesach.

Zainteresowanie nauk społecznych - $\mathrm{w}$ tym także nauki o polityce - teorią społeczną jest ściśle związane z problematyczną naturą wymiaru społecznego ludzkiej egzystencji jako tematu wspólnych badań. Jego wątkiem przewodnim jest uparcie powracająca intuicja, że człowiek to „istota społeczna”, że całe jego istnienie przebiega wśród innych ludzi - razem $z$ innymi, w konkurencji z inny$\mathrm{mi}$, obok innych, w walce $\mathrm{z}$ innymi, we współpracy $\mathrm{z}$ innymi, w konkurencji $\mathrm{z}$ innymi - ale nigdy samotnie! Ta sieć wielokierunkowych relacji między jednostkami to w języku Zbigniewa Herberta „przestrzeń międzyludzka” albo inaczej pole jednostkowo-społeczne nieustannie zmienne i płynne, które należy rozważać w kategoriach relacji i funkcji (Bauman, 2006, 2007; Elias, 1991).

Składnikiem ostatecznym owego pola jednostkowo-społecznego nie są zreifikowane, ponadjednostkowe twory relacyjne, w rodzaju np. systemów lub państw, ani też autonomicznie działające indywidua zwane aktorami albo obywatelami, lecz „zdarzenia społeczne, tzn. działania wielości ludzi wobec siebie, w powiązaniu z innymi, w ramach pewnej wspólnej dla działających sytuacji” (Sztompka, 2008).

Tą niejasną przestrzenią - będącą rezultatem nieustannej konfrontacji, w której każdy, współtworząc ją, opowiada się za swoimi wartościami - interesują się zarówno nauki społeczne, jak i humanistyczne. Świat, który starają się zrozumieć, jest nie tylko światem empirycznym, dostępnym obserwacji i eksperymentowi, złożonym $\mathrm{z}$ faktów i teorematów, to również świat doświadczenia fenomenologicznego, refleksyjnego sądu i działania praktycznego (Turner, 2003; Elliott, 2011). Osią toczonej debaty staje się rozróżnienie między bazą struktur społecznych - z trudem zmieniających się i wyznaczających konieczności, układy i uwarunkowania - a nadbudową polityki i kultury, które wraz z aktorami i decyzjami wchodzą w zakresy swobodnego działania.

Szeroki i zróżnicowany obszar problemów ukryty pod nazwą „teoria społeczna” pozwala dostrzec zarówno „przymusy”, jak i „zakresy swobodnego działania”, unaoczniając tym samym związki między strukturami a podmiotami sprawczymi; skłania do refleksji analitycznej i zarazem zaangażowanej, odróżnia aspekt społeczny od kulturowego i politycznego, próbuje zrozumieć procesy 
historyczne wielkiej skali i cierpliwie poszukuje mechanizmu zmiany społecznej (Baert, Carreira da Silva, 2013).

Bierze na warsztat wszystko; od jednostkowej tożsamości po globalizację, rządzenie państwem, politykę światową i dystrybutywnie ujmowaną kulturę. Unika punktowej (fokusowej) koncentracji na poszczególnych dyscyplinach i subdyscyplinach, uważnie przedstawia wiele zróżnicowanych podejść i perspektyw - niejednokrotnie spornych bądź wymuszających przekraczanie granic pól badawczych zarezerwowanych dla tradycyjnych dyscyplin naukowych (Baylis, Smith, 2008); jednym słowem, dokonuje przeglądu głównych zagadnień, perspektyw i tematów dominujących współcześnie w refleksji nauk społecznych i humanistycznych. Stanowi coś w rodzaju dzieła zbiorowego różnych dyscyplin, stworzonego w odpowiedzi na wspólnie stawiane zagadnienia i problemy związane $\mathrm{z}$ wyjaśnianiem i rozumieniem życia społecznego, zarówno w wymiarze jednostkowym, jak i grupowym.

Perspektywa teorii społecznej proponuje zatem inny punkt widzenia niż te wskazywane przez teorie poszczególnych nauk społecznych, odnoszące się do ustalonych dla nich przedmiotowych pól badawczych. Wyrasta ponad nie, analizuje założenia wyższego rzędu, tak że argumenty, których dostarcza, przebiegają w poprzek tradycyjnych podziałów dyscyplin akademickich. W ten sposób tworzy nadrzędną perspektywę oglądu strategii badawczych dostępnych w naukach społecznych i humanistycznych. Wydaje się ona tym bardziej cenna, że w naukach społecznych termin „teoria” bywa używany swobodnie i często określa się nim każdą pracę, która wykracza poza zwykły opis, a rzadziej - jest dziełem świadomych założeń, $\mathrm{z}$ których bierze początek. Takie teorie nie wynikają bezpośrednio $\mathrm{z}$ ontologicznych założeń ukrytych w paradygmacie, lecz owe supozycje wpływają znacząco na różnice między nimi. Do tych właśnie kwestii odnosi się teoria społeczna; należy ją zatem traktować z uwagą - ale też i ostrożnie - jako rozległą, zróżnicowaną, multidyscyplinarną, sporną i zarazem doniosłą politycznie próbę zmierzenia się z najważniejszymi, pilnymi problemami społeczno-politycznymi współczesności (Turner, 2003; Elliott, 2011).

Zgromadzone w teorii społecznej kontrowersyjne dyskusje i sprzeczne stanowiska odnośnie do wymiaru społecznego rzeczywistości politycznej i mechanizmu jej zmiany nie umożliwiają jednak sformułowania ostatecznie ważnego poglądu na świat; wszelkie zgłaszane propozycje okazują się ograniczone i niepewne, rodzą więcej niepokoju niż pewności, bardziej służą pobudzaniu wyobraźni i dialogowi niż budowaniu mocnych zrębów teorii polityki - pomyślanej jako „skończona” i „nieodwoływalna”.

Niemniej jednak, paradoksalnie - na tym właśnie polega sukces teorii społecznej, która testuje naszą wiedzę! Prowokująco inspiruje, budzi zainteresowanie i zarazem zniechęca, rodzi frustracje i wątpliwości, a mimo to przynosi 
intelektualne profity - zmusza do myślenia (Turner, 2003). Zachęca badaczy do otwartości na to, co nieznane, do przyjęcia szerszej perspektywy i refleksji nad światem, jaki do tej pory uznawaliśmy za oczywisty. Ciekawych i zuchwałych skłania do podejmowania badań społecznych na poziomie meta; badań, które odsłaniają i kwestionują założenia wspólnoty naukowej, w ramach której powstają teorie wypracowane w konkretnych dyscyplinach społecznych. Badań, które są nastawione na samozrozumienie, na pozyskiwanie wiedzy o tym, jak społeczności naukowe rozumieją i korygują same siebie. Co więcej, umożliwiają zdobywanie wiedzy autoreferencyjnej (tj. samowiedzy) - np. odnośnie do konceptualizacji, formułowania (modelowania) dyskursywnego - ujawniającej badaczowi założenia, które do tej pory przyjmował jako oczywiste. Skonfrontowany $\mathrm{z}$ różnymi formami życia społecznego, $\mathrm{z}$ etnocentryzmem i lokalnością swoich przekonań, oczekiwań, spostrzeżeń i wartości, nie traktuje ich jako naturalnych, ustalonych czy uniwersalnych, ale postrzega je jako specyficzne dla własnej kultury, a zarazem realne, związane $\mathrm{z}$ danym czasem i miejscem.

Owe szersze fundamentalne założenia, szczegółowo analizowane w teorii społecznej, to zbiór podstawowych przeświadczeń badacza, kształtujących jego percepcję świata i przekonania co do natury badań naukowych. Bywają postrzegane jako formy światopoglądu, niekiedy ukrywają się pod nazwami paradygmatów, inni badacze nazywają je epistemologiami, ontologiami lub metodologią badań naukowych sensu largo (Lincoln, Guba, 2000, s. 163-188; Crotty, 1998). Wywierają wpływ na wybór strategii badawczych (inaczej: procedur) i konkretnych, przedmiotowych metod gromadzenia, analizy i interpretacji danych. Ich zastosowanie umożliwia realizację $\mathrm{w}$ praktyce badawczej określonego paradygmatem ujęcia i kształtowania teorii szczegółowych, za pomocą których dane nauki społeczne obserwują świat; te założenia powinny być ujawniane i rozpoznawalne, na ogół zostają jednak przemilczane (Slife, Williams, 1995; Krauz-Mozer, 1992).

A przecież warto pamiętać o tym, że rzeczywistość społeczno-polityczna może być postrzegana $\mathrm{w}$ różnych perspektywach ukształtowanych przez przyjęte na wstępie założenia; może być oglądana z punktu widzenia wartości i norm, takich jak sprawiedliwość, pokój, prawo stanowione i innych sądów normatywnych, w tym zagadnień moralnych i politycznych. Badacz może je rozważać i analizować jako idee, pewien projekt świadomościowy, tekst, konstrukcję językową, często jako szlachetne, oddane określonym ideałom i wartościom - ale empirycznie puste - deklaracje ideologiczne. Jednakże wystarczy zmienić założenia i zobaczymy ją inaczej - jako otaczający nas świat społeczny, sprawozdanie z codzienności wypełnione konkretną treścią empiryczną, wiedzą wynikająca $\mathrm{z}$ obserwacji i doświadczenia, zawierającą przede wszystkim określone zdarzenia, interesy, działania i tendencje; zobaczymy w doświad- 
czeniu ekstraspekcyjnym siły materialne, udokumentowane, wyliczone i jasno zdefiniowane.

W tych okolicznościach rysujące się napięcie między stanowiskami nie zasadza się na braku wiedzy, niechlujności myślenia, braku wnikliwości, lecz wynika raczej z subiektywnej orientacji umysłu badaczy.

Analiza ożywionych debat prowadzonych w związku z tymi dylematami zdaje się mieć fundamentalne znaczenie dla współczesnych sporów teoretycznych i metateoretycznych w naukach społecznych. Pozwala również zrozumieć powody, dla których obserwujemy w tych dyscyplinach istnienie tak wielu różnorodnych i często zasadniczo odmiennych orientacji teoretyczno-metodologicznych. Wzrastające zróżnicowanie na poziomie założeń (także pojęć i twierdzeń) skutkuje współcześnie pluralizmem nurtów teoretycznych, z których każdy jest w swoisty sposób jednostronny i ma swoje ograniczenia.

Kontrowersyjne dyskusje toczone wokół tych założeń są nie tyle sporem o strategię badawczą, co raczej rodzajem „gry towarzyskiej”, w której strony dowolnie długo mogą przedstawiać swoje argumenty, nie zyskując dla nich ani ostatecznej aprobaty, ani sprzeciwu, ponieważ uczestniczą w dyspucie dotyczącej kwestii w zasadzie nierozstrzygalnych. Co najwyżej przystąpienie do tej gry podzieli uczestniczących w nich badaczy na zwolenników naturalizmu bądź antynaturalizmu (spór metodologiczny), wyznawców obiektywizmu albo konstruktywizmu (spór ontologiczny), na tych, którzy uznają wartościowanie za niezbywalnie obecne w nauce, i tych, którzy opowiadają się za jej neutralnością (spór epistemologiczny). Polemizują zwolennicy holizmu $\mathrm{z}$ obrońcami indywidualizmu, stronnicy determinizmu występują przeciwko rzecznikom aktywizmu - każda ze stron ma swoje racje i wskazuje słabe punkty opozycyjnego stanowiska. Jednakże należy wątpić w możliwość ostatecznego rozstrzygnięcia, ponieważ nie daje się łatwo empirycznie potwierdzić bądź odrzucić argumentacji właściwej dla danego założenia.

Z pomocą może przyjść propozycja „przeliczania różnych perspektyw” polegająca na badaniu i testowaniu przydatności teorii w skutecznym wyjaśnianiu rzeczywistości społeczno-politycznej bądź przekonywającej interpretacji różnych jej aspektów. Ten dylemat wynikający z dualistycznego charakteru nauki powoli uczymy się uznawać za szansę. Teoria polityki stoi pomiędzy tymi frontami na pozycji „granicznej egzystencji”; to daje jej szansę polegającą przede wszystkim na tym, że może określić swoją pozycję względnie swobodnie $\mathrm{w}$ transdyscyplinarnej perspektywie.

Wspiera ją obserwacja wskazująca, że pewne twierdzenia w danym miejscu i czasie mogą być „bardziej prawdziwe niż inne” na tej podstawie, że ludzie wierzą w ich prawdziwość. Przyjęcie takiej strategii prowadzi w konsekwencji do szukania odpowiedzi nie tyle na pytanie, jakiego rodzaju wiedza okazuje 
się a priori słuszna, ale na pytanie: jak wytwarzamy wiedzę, której przedmiot jest „plastyczny”, „czasoprzestrzenny”. Jaki proces sprawia, że w pewnym miejscu i czasie dane stanowisko uznajemy za „prawdziwe”, a w innym za „fałszywe”? Skłania również do podejmowania śmiałego dialogu z różnymi innymi teoriami i dokonywania częściowych syntez teoretycznych. Takie otwarte, refleksyjne nastawienie sprzyja $\mathrm{w}$ politologii rozwojowi szeroko rozumianych badań teoretycznych, ponieważ postęp w tej dziedzinie osiąga się zawsze dzięki ścieraniu się różnych paradygmatów, stanowisk czy przekonań. To perspektywa, w której teoretyzowanie w kontekście polityki jawi się jako szczególna, uogólniona forma wysiłku podejmowanego wspólnie przez wielu po to, aby zrozumieć społeczeństwo ludzkie ujęte w struktury, w ramach których dokonywana jest alokacja wartości.

Pomóżmy sobie wzajemnie, podejmując wespół trud, by zrozumieć, o co nam chodzi, gdy rozprawiamy o teoriach polityki; wszak politologia pozycjonuje swoje teorie przez własne odniesienie do fundamentalnych aksjomatów, odmiennie interpretowanych w głównych nurtach - światopoglądowo zorientowanych - nauk społecznych (Czaputowicz, 2007, s. 53). Spotkajmy się na płaszczyźnie teorii społecznej i spróbujmy wychylić się poza ciasny obszar przedmiotowy politologii. To tylko wzbogaci naszą wiedzę, nauczy swoistej pokory poznawczej wobec złożoności rzeczywistości społecznej i różnorakich prób jej interpretacji. Teoretyk, wywiązujący się ze swoich obowiązków, powinien najpierw zostać wytrawnym znawcą różnorodnych kierunków myśli teoretycznej w politologii, potem zobaczyć je w zderzeniu $\mathrm{z}$ teorią społeczną, by na koniec móc się stać twórczym i niedogmatycznym wyznawcą którejkolwiek z nich, a także by móc zrozumieć zarówno elementy wspólne, jak i naturę różnic między nimi.

To ważny kierunek refleksji badawczej w odniesieniu do teorii! Zwłaszcza dzisiaj, gdy nie istnieje żaden kanon ostatecznie akceptowanych koncepcji naukowych. Moc teorii społecznej leży właśnie w tolerancji dla sprzecznych poglądów i przyjmowaniu wszelkich nowości poważnie, dopóki nie okażą się nieprawdziwe, na mocy kryteriów jednego, $\mathrm{w}$ dalszym ciągu dominującego, modelu naukowości; jego rezydua trwają, mimo historyzacji niektórych epistemologów.

Aktywne i zarazem krytyczne uczestniczenie w tych sporach - toczonych $\mathrm{w}$ imię racjonalności naukowej, $\mathrm{w}$ atmosferze myślenia sceptycznego, z pozytywnym nastawieniem do Oświecenia i zarazem do współczesnego obowiązku kwestionowania twierdzeń oraz krytycznej postawy wobec autorytetów i spekulacji - jest warunkiem intelektualnej i moralnej rzetelności w badaniach naukowych. Współcześnie zaczynamy rozumieć, że w przeciwieństwie do dawnych dysput intelektualnych drogi dochodzenia do prawdy nie są jałowymi akademickimi dyskusjami - prędzej czy później będą miały wpływ na życie każdego $\mathrm{z}$ nas. 


\section{Literatura}

Alexander, J.C. (1982). Theoretical Logic in Sociology, vol. 1. Berkeley: University of California Press.

Baert, P., Carreira da Silva, F. (2013). Teorie społeczne w XX wieku i dzisiaj, przeł. S. Burdziej. Kraków: Zakład Wydawniczy Nomos.

Bauman, Z. (2006). Płynna nowoczesność, przeł. T. Kunz. Kraków: Wydawnictwo Literackie.

Bauman, Z. (2007). Płynne życie, przeł. T. Kunz. Kraków: Wydawnictwo Literackie.

Baylis, J., Smith, S. (red.) (2008). Globalizacja polityki światowej. Wprowadzenie do stosunków międzynarodowych, przeł. M. Filary, M. Góra i in. Kraków: Wydawnictwo Uniwersytetu Jagiellońskiego.

Bell, D. (1960). The End of Ideology. New York: The Free Press.

Crotty, M. (1998). The Foundations of Social Research: Meaning and Perspective in the Research Process. London: Sage.

Czaputowicz, J. (2007). Teorie stosunków międzynarodowych. Krytyka i systematyzacja. Warszawa: Wydawnictwo Naukowe PWN.

della Porta, D., Keating, M. (eds.) (2008). Approaches and Methodologies in the Social Sciences: A Pluralist Perspective. Cambridge: Cambridge University Press.

Elias, N. (1991). The Society of Individuals. Oxford: Blackwell.

Elliott, A. (2011). Współczesna teoria społeczna. Wprowadzenie, przeł. P. Tomanek, Warszawa: Wydawnictwo Naukowe PWN.

Faia, M.A. (1986). Dynamic Functionalism: Strategy and Tactics. Cambridge: Cambridge University Press.

Goldstein, G., Keohane, R.O. (eds.) (1993). Ideas and Foreign Policy: Beliefs, Institutions and Political Change. Ithaca-New York: Cornell University Press.

Heller, M. (2016). Filozofia nauki. Kraków: Copernicus Center Press.

Krauz-Mozer, B. (1992). Metodologiczne problemy wyjaśniania w nauce o polityce. Kraków: Wydawnictwo Uniwersytetu Jagiellońskiego.

Laslett, P. (1956). “Introduction”. In: P. Laslett (ed.). Philosophy, Politics and Society, series I. Oxford: Blackwell.

Lincoln, Y.S., Guba, E.G. (2000). "Paradigmatic Controversies, Contradictions and Emerging Confluences”. In: Y.S. Lincoln, E.G. Guba (eds.). Handbook of Qualitative Research. Thousand Oaks: Sage.

Popper, K.R. (1992). Wiedza obiektywna, przeł. A. Chmielewski, Warszawa: PWN.

Rheinberger, H.J. (2015). Epistemologia historyczna, przeł. J. Surman. Warszawa: Oficyna Naukowa.

Sartori, G. (1994). Teoria demokracji, przeł. P. Amsterdamski, D. Grinberg. Warszawa: PWN. 
Seidman, S. (2006). „Koniec teorii socjologicznej: ponowoczesna nadzieja”. W: A. Jasińska-Kania, L. Nijakowski, J. Szacki, M. Ziółkowski (red.). Współczesne teorie socjologiczne, t. 1, przeł. A. Zawadzka, W. Derczyński. Warszawa: Wydawnictwo Naukowe Scholar.

Skinner, Q. (ed.) (1990). The Return of Grand Theory in the Human Science. Cambridge: Cambridge University Press.

Slife, B.D., Williams, R.N. (1995). What's behind the Research? Discovering Assumptions in the Behavioral Science. Thousand Oaks: Sage.

Snow, C.P. (1993). The Two Cultures. Cambridge: Cambridge University Press.

Szacki, J. (2002). Historia myśli socjologicznej, wyd. nowe. Warszawa: Wydawnictwo Naukowe PWN.

Sztompka, P. (2008). „Życie codzienne - temat najnowszej socjologii”. W: P. Sztompka, M. Bogunia-Borowska (red.). Socjologia codzienności. Kraków: Wydawnictwo Znak.

Turner, B.S. (red.) (2003). Teoria społeczna, przeł. G. Woroniecka, A. Gąsior-Niemiec. Warszawa: Oficyna Naukowa.

\section{Streszczenie}

Teoretyczne myślenie o polityce to domena emocjonalnych sporów, antynomii związanych z rozumieniem fenomenu nauki czy też powodów nierozstrzygalnych kontrowersji dotyczących podstaw uznawanych światopoglądów. Uczestniczą w tej dyskusji, we właściwym dla siebie stylu, zarówno nauki społeczne, jak i nauki humanistyczne; politologia i wypracowane w jej obszarze przedmiotowym teorie mieszczą się pomiędzy nimi. Ich rozpatrywanie nie ma znamion spokojnej, rzeczowej polemiki, przebiega $\mathrm{z}$ naruszaniem reguł racjonalności naukowej. Niejednokrotnie ma charakter konfesyjny: spierające się strony, zamiast dyskursywnego objaśnienia zajmowanego stanowiska i przytoczenia stosownych argumentów, ograniczają się do wyjawienia własnego „wyznania wiary” i z tej pozycji zdeprecjonowania kontrpartnera. W opinii autorki teoria społeczna i w jej planie rozważane politologiczne teorie polityki mogłyby ułatwić ustalenie i zrozumienie źródeł poglądów generujących różnice.

Słowa kluczowe: nauki społeczne, teoria społeczna, teoria polityki, teoretyzowanie, fenomen nauki 